\title{
KEBIJAKAN DESENTRALISASI DAN KETIMPANGAN CAPAIAN PEMBANGUNAN WILAYAH DI INDONESIA
}

\section{Sekar Dewinda Santi dan Doddy Aditya Iskandar}

Universitas Gadjah Mada (UGM) Yogyakarta, Indonesia

Email: sekar.dewinda.s@mail.ugm.ac.id dan doddy@ugm.ac.id

\begin{tabular}{l}
\hline INFO ARTIKEL \\
\hline Diterima \\
25 Februari 2021 \\
Diterima dalam bentuk revisi \\
15 Maret 2021 \\
Diterima dalam bentuk revisi
\end{tabular}

Keywords:

decentralization policy; income inequality; human development

\begin{abstract}
Inequality is one of the problems that can be found in Indonesia. One solution that can be done by the Indonesian government to resolve inequality is the policy of decentralization. The purpose of this study is to examine the effect of the government in the form of fiscal decentralization on inequality in regional development indicators and to analyze fiscal decentralization policy policies in reducing inequality in regional development indicators in Indonesia. This research is based on two regions, namely regencies/cities in the provinces of East Java and West Java, with a classification based on the location of the region, namely coastal and inland areas. Difference-in-differences analysis were used in this study. The results of the analysis show that the fiscal decentralization policy affects reducing inequality in regional development achievement indicators in coastal and inland areas in each province. Another finding is that after the fiscal decentralization policy, inequality in the indicators of development outcomes has converged in the two regions.
\end{abstract}

\begin{abstract}
ABSTRAK
Ketimpangan merupakan salah satu permasalahan pembangunan yang masih ditemui di Indonesia. Salah satu cara pemerintah Indonesia mengatasi masalah ketimpangan adalah penerapan kebijakan desentralisasi. Tujuan dari penelitian ini adalah untuk menguji pengaruh kebijakan pemerintah berupa desentralisasi fiskal terhadap ketimpangan pada capaian indikator pembangunan wilayah serta menganalisis efektivitas kebijakan desentralisasi fiskal dalam mengurangi ketimpangan pada capaian indikator pembangunan wilayah di Indonesia. Penelitian ini berfokus pada dua wilayah yaitu Kabupaten/Kota di Provinsi Jawa Timur dan Jawa Barat, dengan klasifikasi berdasarkan pada letak wilayah yaitu wilayah pesisir dan inland. Metode
\end{abstract}




\begin{tabular}{|c|c|}
\hline $\begin{array}{l}\text { Kata Kunci: } \\
\text { kebijakan desentralisasi; } \\
\text { ketimpangan pendapatan; } \\
\text { pembangunan manusia }\end{array}$ & $\begin{array}{l}\text { analisis difference-in-differences digunakan dalam } \\
\text { penelitian ini. Hasil analisis menunjukkan bahwa } \\
\text { kebijakan desentralisasi fiskal memiliki pengaruh } \\
\text { terhadap penurunan ketimpangan pada indikator capaian } \\
\text { pembangunan wilayah di daerah pesisir dan inland pada } \\
\text { masing-masing provinsi. Temuan lain yaitu setelah } \\
\text { adanya kebijakan desentralisasi fiskal, ketimpangan } \\
\text { indikator capaian hasil pembangunan mengalami } \\
\text { konvergensi di kedua wilayah. }\end{array}$ \\
\hline
\end{tabular}

Coresponden Author

Email: sekar.dewinda.s@mail.ugm.ac.id Artikel dengan akses terbuka dibawah lisensi

\section{Pendahuluan}

Ketimpangan antar wilayah merupakan salah satu permasalahan yang masih dihadapi negara-negara di dunia khususnya di negara berkembang, tidak terkecuali di Indonesia (Bunnell et al., 2013). Ketimpangan menjadi isu penting melihat kondisi wilayah Indonesia yang cukup luas dan terdiri dari berbagai wilayah adminsitratif dengan karakteristiknya masing-masing. Tingkat pendapatan, modal manusia, ketersediaan layanan dasar dan infrastruktrur hingga kondisi geografis merupakan beberapa penyebab ketimpangan di Indonesia. Ketimpangan wilayah dapat disebabkan oleh perbedaan aktivitas ekonomi, pendapatan, dan indikator sosial (Dafflon, 2015). Salah satu cara untuk mengukur ketimpangan adalah dengan menggunakan Indeks Gini. Dalam 5 tahun terakhir, rasio gini di Indonesia menunjukkan trend negatif. Indonesia berhasil menurunkan tingkat ketimpangannya dari tingkat ketimpangan sedang $(0,41>0,5)$ menjadi ketimpangan rendah $(<0,4)$. Penurunan ini sejalan dengan penurunan nilai kemiskinan relatif dari populasi penduduk di Indonesia.

Meskipun trend penurunan rasio gini dan tingkat kemiskinan terus terjadi selama 5 (tahun) terakhir, namun jika dilihat berdasarkan dimensi spasial, ketimpangan masih terjadi khususnya antara daerah barat dengan daerah timur Indonesia. Data tahun 2018 menunjukan bahwa Pulau Papua secara rata-rata memiliki rasio gini paling besar relatif terhadap seluruh pulau besar di Indonesia dengan nilai sebesar 0,395. Uniknya, Pulau Jawa-Bali ternyata juga memiliki rasio gini yang cukup tinggi relatif terhadap pulau lain yaitu sebesar 0,381. Selain itu, secara rata-rata persentase penduduk miskin di Pulau Papua paling besar dari seluruh pulau besar di Indonesia yaitu sebesar 25,045\% dari total penduduk di Pulau Papua. Berikut merupakan peta persebaran yang menunjukkan ketimpangan antar pulau di Indonesia. 

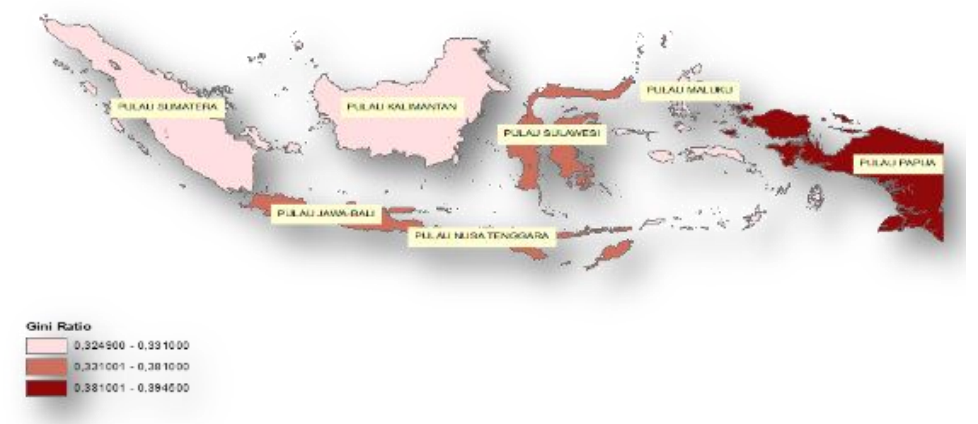

\section{Gambar 1 \\ Rasio Gini Berdasarkan Pulau di Indonesia Tahun 2018 Sumber: Badan Pusat Statistik, diolah (2019)}

Ketimpangan spasial ini akan memicu pemerintah untuk mengeluarkan sebuah paket kebijakan menurut (Phelps et al., 2014). Salah satu kebijakan yang dianggap dapat menjadi alternatif penyelesaian masalah ketimpangan adalah kebijakan desentralisasi. Desentralisasi merupakan salah satu bentuk penyerahan wewenang dari pemerintah pusat ke daerah dengan tujuan efisiensi publik, pembangunan, dan pertumbuhan ekonomi (Kusuma, 2016) dalam (Phelps et al., 2014).

Hubungan kebijakan desentralisasi dengan ketimpangan antar wilayah ini dapat dilihat dari dua sisi, kebijakan desentralisasi secara spesifik memperhatikan waktu dan lokasi dalam mengimplementasikan kebijakan sehingga dapat berpengaruh terhadap kesejahteraan masyarakat menurut (Kalirajan \& Otsuka, 2012). Desentralisasi dapat meningkatkan kompetisi antar pemerintah daerah sehingga dapat memicu pertumbuhan sektor publik di masing-masing daerah (Naylor et al., 2019) dalam (White, 2011). Selain itu, dengan adanya desentralisasi, pemerintah daerah memiliki informasi tentang kekuatan dan kelemahan daerahnya sehingga dapat membuat kebijakan daerah yang lebih efektif (Phelps et al., 2014). Desentralisasi juga akan memperkuat pertumbuhan wilayah dan berkontribusi pada pemerataan. Di sisi lain, desentralisasi justru menyebabkan kurangnya peran pemerintah pusat untuk mendukung wilayah yang lebih miskin sehingga dapat menyebabkan ketimpangan menurut (Fadzil \& Nyoto, 2011). Desentralisasi justru akan menyebabkan ketimpangan antar wilayah. Dampak adanya desentralisasi di negara berkembang akan menyebabkan masalah koordinasi, regulasi yang berlebihan, biaya administatif yang tinggi, dan kualitas pemerintah daerah yang rendah (Hill, 2014) dalam (Phelps et al., 2014).

Di Indonesia, sebagai bentuk pelaksanaan desentralisasi, pemerintah pusat menerapkan kebijakan desentralisasi fiskal yaitu perimbangan keuangan ke pemerintah daerah, yang diatur oleh Undang-Undang Nomor 2 Tahun 2015 tentang Perubahan Kedua Atas Undang-Undang No 23 Tahun 24 Tentang Pemerintahan Daerah serta UU No.33 Tahun 2004 tentang Perimbangan Keuangan Antara Pemerintah Pusat dan Pemerintah Daerah (Yustisia, 2015). Dengan adanya desentralisasi fiskal ini maka pemerintah pusat melimpahkan kewenangan di segala bidang kecuali kewenangan dalam bidang politik 
luar negeri, pertahanan, keamanan, yustisi, moneter, dan fiskal serta keagamaan (Hadi \& Saragih, 2013). Pada pelimpahan kewenangan ini juga diikuti dengan penyerahan sumber-sumber pendanaan, seperti perpajakan maupun bantuan pendanaan dalam bentuk dana transfer. Pelaksanaan desentralisasi fiskal di Indonesia merupakan desentralisasi fiskal dari sisi belanja (expenditure) bukan dari sisi pendapatan (revenue) (Kharisma, 2013). Desentralisasi fiskal ini bertujuan mengurangi ketimpangan yang mungkin terjadi baik antar daerah (horisontal imbalances) maupun antara pemerintah pusat dan daerah (vertical imbalances). Adanya desentralisasi fiskal, diharapkan pemerintah daerah dapat mengalokasikan belanja sesuai kebutuhan pada masing-masing daerah sehingga dapat digunakan untuk pembangunan daerah yang bertujuan dapat mengurangi ketimpangan antar wilayah.

Berdasarkan penjelasan diatas maka penelitian ini bertujuan mengidentifikasi pengaruh serta efektivitas dari kebijakan pemerintah berupa desentralisasi fiskal terhadap ketimpangan pada indikator capaian pembangunan antar wilayah di Indonesia.

\section{Metode Penelitian}

Pada penelitian ini menggunakan pendekatan deduktif-kuantitatif. Pendekatan deduktif merupakan pendekatan yang menggunakan logika untuk menarik satu atau lebih kesimpulan (conclusion) berdasarkan seperangkat premis yang diberikan (Hidayat, 2017). Sedangkan metode kuantitatif adalah metode penelitian yang berlandaskan pada filsafat positivisme, digunakan untuk meneliti pada populasi atau sampel tertentu, teknik pengambilan sampel pada umumnya dilakukan secara random, pengumpulan data menggunakan instrumen penelitian, analisis data bersifat kuantitatif/statistik dengan tujuan untuk menguji hipotesis yang telah ditetapkan (Faguet, 2014). Metode pengumpulan data pada penelitian ini dilakukan dengan mengumpulkan data sekunder berupa dokumen yang bersumber dari Badan Pusat Statistik Indonesia, Provinsi, Kabupaten/Kota, maupun dokumen pendukung lainnya dengan periode waktu 3 tahun yakni tahun 2015 hingga 2017. Setelah seluruh data tersebut dikumpulkan maka keseluruhan data ditabulasi dalam 1 dokumen hasil tabulasi data. Hasil tabulasi data selanjutnya dianalisis menggunakan alat bantu analisis berupa software pengolah data statistik. Populasi dari penelitian ini adalah wilayah yang berada pada tingkat kabupaten/kota di Indonesia. Adapun sampel dari penelitian ini adalah kabupaten/kota yang berada di Provinsi Jawa Barat dan Jawa Timur. Jumlah sampel yang digunakan adalah 64 kabupaten/kota yang terdiri dari 26 kabupaten/kota di Jawa Barat dan 38 kabupaten/kota di Jawa Timur. Selain itu, pada sampel penelitian digunakan klasifikasi berdasarkan letak wilayah, antara wilayah pesisir dan inland. Pesisir dan inland digunakan sebagai perbandingan karena wilayah berdasarkan kedua posisi geografis tersebut masing-masing memiliki karakteristik yang berbeda.

Pada penelitian ini pun digunakan yang digunakan adalah penggunan metode analisis Difference-in-Difference (DID) dan analisis jalur. (Nasution, 2017) menjelaskan teknik analisis DID merupakan salah satu teknik analisis statistik sering digunakan untuk menganalisis kebijakan. Perhitungan DID digunakan untuk mengidentifikasi 
intervensi yang bersifat spesifik seperti perubahan kebijakan atau penerapan hukum (Passage of Law). Pada analisis ini, dilakukan perbandingan keluaran antara sebelum dan sesudah intervensi pada kelompok yang terpengaruh intervensi (treatment group) dan pada kelompok yang tidak terpengaruh intervensi (control group). Model DID pada penelitian ini yaitu sebagai berikut:

Ketimpangan $_{i t}=\delta_{1}+\alpha_{i 0}+\alpha_{i l} t+\beta_{1}$ Desentralisasit $_{i} * D U_{t}+z^{\prime}{ }_{i t} \gamma+u_{i t}$,

PembangunanManusia $_{i t}=\delta_{1}+\alpha_{i 0}+\alpha_{i l} t+\beta_{1}$ Desentralisasi $_{i} * D U_{t}+z^{\prime}{ }_{i t} \gamma+u_{i t}$,

Perekonomian $_{i t}=\delta_{1}+\alpha_{i 0}+\alpha_{i 1} t+\beta_{1}$ Desentralisasi $_{i} * D U_{t}+z^{\prime}{ }_{i t} \gamma+u_{i t}$,

$$
i=1,2, \ldots, N, t=1,2, \ldots, T
$$

Ketimpangan, pembangunan manusia, dan perekonomian adalah indikator capaian pembangunan wilayah pada individu i pada waktu $\mathrm{t}, \mathrm{u}_{\mathrm{it}}$ adalah skalar, $\delta_{1}$ adalah time fixed effect, $\alpha_{\mathrm{i} 0}$ adalah individual fixed effect, $\alpha_{\mathrm{i} 1 \mathrm{t}}$ adalah individual-specific linier time trend coefficient desentralisasi menjelaskan indikator untuk individu pada treatment group; nilai 1 apabila individu merupakan treatment group dan nilai 0 apabila individu i merupakan control group. $D U_{t}$ menjelaskan indikator untuk periode waktu pada postpolicy-change; nilai 1 adalah perubahan setelah kebijakan dan nilai 0 untuk lainnya.

\section{Hasil dan Pembahasan}

Pada bagian ini dilakukan analisis menggunakan metode Difference-in-Difference (DID). Pada analisis DID ini baseline yang digunakan adalah tahun 2015 yaitu ketika dikeluarkannya kebijakan otonomi daerah dan desentralisasi fiskal di Indonesia paling akhir. Kebijakan tersebut diatur dalam Undang-Undang Nomor 2 Tahun 2015 tentang Perubahan Kedua Atas Undang-Undang Nomor 23 Tahun 2014 Tentang Pemerintahan Daerah, serta UU No. 33 Tahun 2004 tentang Perimbangan Keuangan Antara Pemerintah Pusat dan Pemerintah Daerah. Adanya kebijakan tersebut artinya semakin banyak kewenangan yang diserahkan kepada daerah oleh pemerintah pusat. Tujuan dari analisis ini adalah melihat pengaruh dari adanya kebijakan desentralisasi fiskal terhadap capaian indikator pembangunan daerah serta dapat mengetahui gap diantara daerah yang termasuk dalam treatment group dengan daerah yang termasuk dalam control group sebelum dan sesudah adanya kebijakan. Adapun rancangan penelitian dengan metode DID adalah sebagai berikut:

\section{Tabel 1}

\section{Rancangan Penelitian dengan Metode DID}

\begin{tabular}{llll}
\hline No & Grup & Kabupaten & Desentralisasi Fiskal \\
\hline $\mathbf{1}$ & Treatment Group & $\begin{array}{l}\text { Kabupaten/Kota yang termasuk } \\
\text { dalam kategori Inland di pada } \\
\text { tiap provinsi }\end{array}$ & 2015 vs 2016 \\
& & 2015 vs 2017 \\
\hline $\mathbf{2}$ & Control Group & $\begin{array}{l}\text { Kabupaten/Kota yang termasuk } \\
\text { dalam kategori Pesisir pada tiap } \\
\text { provinsi }\end{array}$ & 2015 vs 2016 \\
& & 2015 vs 2017 \\
\hline
\end{tabular}

Sumber: Analisis Penulis (2020) 
Pada bagian ini dijelaskan mengenai hasil analisis DID pada setiap indikator capaian hasil pembangunan di Provinsi Jawa Timur. Indikator pertama yaitu indikator ketimpangan. Berdasarkan analisis DID dapat dilihat bahwa dengan kebijakan desentralisasi fiskal berpengaruh menurunkan gap ketimpangan antara daerah inland dengan daerah pesisir pada tahun 2016 di Kabupaten/Kota Provinsi Jawa Timur. Sebelum kebijakan diterapkan, diketahui bahwa perbedaan antara daerah inland dan daerah pesisir adalah sebesar 0,029 kemudian setelah adanya kebijakan maka perbedaan tersebut berkurang menjadi 0,027. Namun pada tahun 2017, perbedaan antara kedua daerah tersebut kembali mengalami peningkatan, yaitu menjadi 0,029. Artinya, pada tahun pertama setelah kebijakan, gap diantara kedua daerah semakin sempit, kemudian kembali melebar pada tahun kedua setelah kebijakan. Meskipun gap antara kedua daerah berkurang, namun berdasarkan analisis tersebut adanya kebijakan desentralisasi fiskal tersebut justru memiliki dampak pada peningkatan ketimpangan sebelum maupun sesudah kebijakan.

Indikator kedua yaitu indikator pembangunan manusia. Berdasarkan analisis DID dapat dilihat bahwa dengan kebijakan desentralisasi fiskal berpengaruh menurunkan gap pembangunan manusia antara daerah inland dengan daerah pesisir pada tahun 2016 di Kabupaten/Kota Provinsi Jawa Timur. Sebelum kebijakan diterapkan, diketahui bahwa perbedaan antara daerah inland dan daerah pesisir adalah sebesar 5.798 kemudian setelah adanya kebijakan maka perbedaan tersebut berkurang menjadi 5.646. Begitu pula pada tahun 2017, perbedaan antara kedua daerah tersebut mengalami penurunan, yaitu menjadi 5,572. Artinya, pada tahun pertama setelah kebijakan, gap diantara kedua daerah semakin sempit, kemudian terus menyempit pada tahun kedua setelah kebijakan. Berdasarkan analisis tersebut adanya kebijakan desentralisasi fiskal berdampak pada peningkatan kualitas pembangunan manusia sebelum maupun sesudah kebijakan.

Indikator ketiga yaitu indikator ekonomi. Berdasarkan analisis DID dapat dilihat bahwa dengan kebijakan desentralisasi fiskal berpengaruh menurunkan gap pendapatan antara daerah inland dengan daerah pesisir pada tahun 2016 di Kabupaten/Kota Provinsi Jawa Timur. Sebelum kebijakan diterapkan, diketahui bahwa perbedaan antara daerah inland dan daerah pesisir adalah sebesar -0,635 kemudian setelah adanya kebijakan maka perbedaan tersebut berkurang menjadi -0,611. Begitu pula pada tahun 2017, perbedaan antara kedua daerah tersebut mengalami penurunan, yaitu menjadi -0,608. Artinya, pada tahun pertama setelah kebijakan, gap diantara kedua daerah semakin sempit, kemudian terus menyempit pada tahun kedua setelah kebijakan. Namun, baik sebelum dan sesudah kebijakan, daerah pesisir memiliki kinerja pendapatan yang lebih baik daripada daerah inland. Berdasarkan analisis tersebut adanya kebijakan desentralisasi fiskal berdampak pada peningkatan ekonomi sebelum maupun sesudah kebijakan. 


\section{Tabel 2}

Hasil Analisis Difference-In-Differences Indikator Capaian Hasil Pembangunan Jawa Timur, 2015 vs 2016

\begin{tabular}{|c|c|c|c|c|c|c|}
\hline \multirow{3}{*}{$\begin{array}{c}\text { Dampak Desentralisasi } \\
\text { Fiskal Terhadap } \\
\text { Indikator Capaian Hasil } \\
\text { Pembangunan }\end{array}$} & \multicolumn{6}{|c|}{2016} \\
\hline & \multicolumn{3}{|c|}{$2015 v s 2016$ (Before) } & \multicolumn{3}{|c|}{$2015 v s 2016$ (After) } \\
\hline & Control & Treated & $\operatorname{Diff}(\mathrm{T}-\mathrm{C})$ & Control & Treated & $\operatorname{Diff}(\mathrm{T}-\mathrm{C})$ \\
\hline $\begin{array}{l}\text { Ketimpangan } \\
\text { (Indeks GINI) }\end{array}$ & 0.283 & 0.312 & $\begin{array}{c}0.029 * * * \\
(0.010)\end{array}$ & 0.329 & 0.356 & $\begin{array}{c}0.027 * * * \\
(0.007)\end{array}$ \\
\hline $\begin{array}{c}\text { Pembangunan Manusia } \\
\text { (IPM) }\end{array}$ & 65.224 & 71.022 & $\begin{array}{l}5.798 * * * \\
(1.475)\end{array}$ & 66.365 & 72.011 & $\begin{array}{c}5.646^{* * * *} \\
(1.043)\end{array}$ \\
\hline $\begin{array}{l}\text { Ekonomi } \\
\text { (PDRB) }\end{array}$ & 10.112 & 9.447 & $\begin{array}{c}-0.635 * * \\
(0.277)\end{array}$ & 10.179 & 9.567 & $\begin{array}{c}-0.611 * * * \\
(0.196)\end{array}$ \\
\hline
\end{tabular}

Keterangan: ***Signifikan pada level 1\%; **Signifikan pada level 5\%; *Signifikan pada level 10\%

Sumber: Analisis Penulis (2020)

Tabel 3

Hasil Analisis Difference-In-Differences Indikator Capaian Hasil Pembangunan Jawa Timur, 2015 vs 2017

\begin{tabular}{|c|c|c|c|c|c|c|}
\hline \multirow{3}{*}{$\begin{array}{c}\text { Dampak Desentralisasi Fiskal } \\
\text { Terhadap Indikator Capaian } \\
\text { Hasil Pembangunan }\end{array}$} & \multicolumn{6}{|c|}{2017} \\
\hline & \multicolumn{3}{|c|}{ (Before) } & \multicolumn{3}{|c|}{ (After) } \\
\hline & Control & Treated & $\begin{array}{l}\text { Diff }(\mathrm{T}- \\
\mathrm{C})\end{array}$ & Control & Treated & $\begin{array}{l}\text { Diff }(\mathrm{T}- \\
\mathrm{C})\end{array}$ \\
\hline $\begin{array}{l}\text { Ketimpangan } \\
\text { (Indeks GINI) }\end{array}$ & 0.283 & 0.312 & $\begin{array}{c}0.029 * * * \\
(0.010)\end{array}$ & 0.323 & 0.352 & $\begin{array}{c}0.029 * * * \\
(0.007)\end{array}$ \\
\hline $\begin{array}{l}\text { Pembangunan Manusia } \\
\text { (IPM) }\end{array}$ & 65.224 & 71.022 & $\begin{array}{c}5.798 * * * \\
(1.475)\end{array}$ & 66.682 & 72.254 & $\begin{array}{c}5.572 * * * \\
(1.044)\end{array}$ \\
\hline $\begin{array}{l}\text { Ekonomi } \\
\text { (PDRB) }\end{array}$ & 10.112 & 9.447 & $\begin{array}{c}-0.635 * * \\
(0.277)\end{array}$ & 10.203 & 9.595 & $\begin{array}{c}- \\
0.608 * * * \\
(0.196)\end{array}$ \\
\hline
\end{tabular}

Keterangan: ***Signifikan pada level 1\%; **Signifikan pada level 5\%; *Signifikan pada level 10\%

Sumber: Analisis Penulis (2020)

Analisis DID juga disajikan dalam bentuk grafik. Tujuannya adalah agar dapat melihat dampak dari kebijakan desentralisasi fiskal terhadap indikator capaian pembangunan dan juga gap antara daerah inland dengan daerah pesisir di Jawa Timur. Adapun dampak dan gap tersebut disajikan pada grafik berikut:

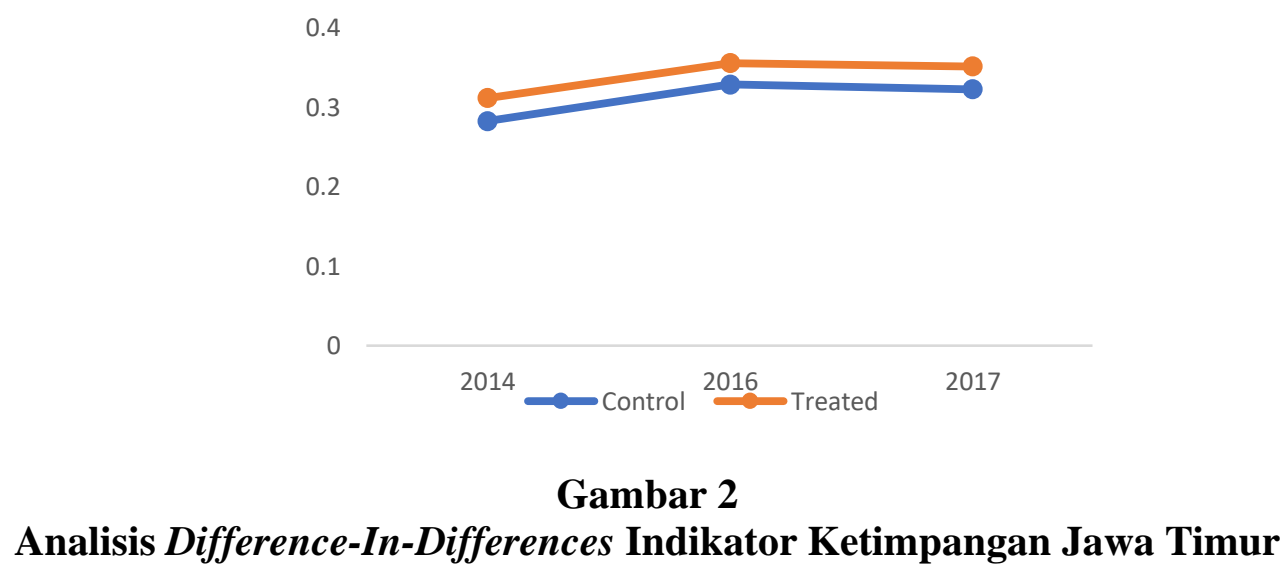


Sumber: Analisis Penulis (2020)

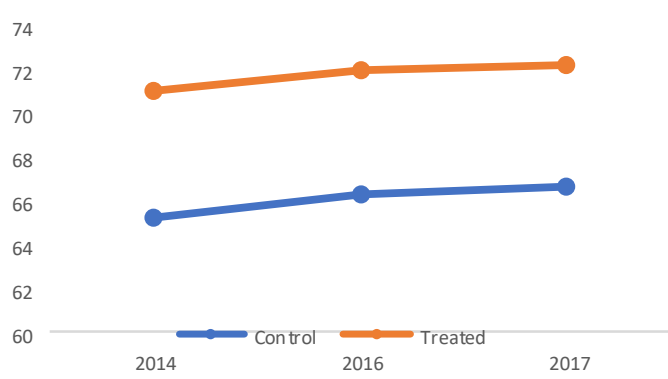

Gambar 3

Analisis Difference-In-Differences Indikator Pembangunan Manusia Jawa Timur

Sumber: Analisis Penulis (2020)

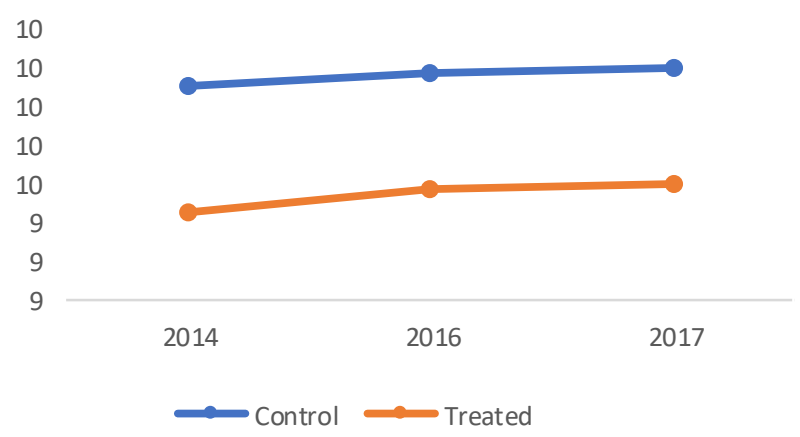

\section{Gambar 4 \\ Analisis Difference-In-Differences Ekonomi Jawa Timur \\ Sumber: Analisis Penulis (2020)}

Pada bagian ini dijelaskan mengenai hasil analisis DID pada setiap indikator capaian hasil pembangunan di Provinsi Jawa Barat. Indikator pertama yaitu indikator ketimpangan. Berdasarkan analisis DID dapat dilihat bahwa dengan kebijakan desentralisasi fiskal berpengaruh menurunkan gap ketimpangan antara daerah inland dengan daerah pesisir pada tahun 2016 di Kabupaten/Kota Provinsi Jawa Barat. Sebelum kebijakan diterapkan, diketahui bahwa perbedaan antara daerah inland dan daerah pesisir adalah sebesar 0,042 kemudian setelah adanya kebijakan maka perbedaan tersebut berkurang menjadi 0,037. Berbeda dengan Jawa timur, pada tahun 2017 perbedaan antara kedua daerah tersebut mengalami penurunan, yaitu menjadi 0,030. Artinya, pada tahun pertama setelah kebijakan, gap diantara kedua daerah semakin sempit, kemudian terus menyempit pada tahun kedua setelah kebijakan. Meskipun gap antara kedua daerah berkurang, namun berdasarkan analisis tersebut adanya kebijakan 
desentralisasi fiskal tersebut justru memiliki dampak pada peningkatan ketimpangan sebelum maupun sesudah kebijakan.

Indikator kedua yaitu indikator pembangunan manusia. Berdasarkan analisis DID dapat dilihat bahwa dengan kebijakan desentralisasi fiskal berpengaruh meningkatkan gap pembangunan manusia antara daerah inland dengan daerah pesisir pada tahun 2016 di Kabupaten/Kota Provinsi Jawa Barat. Sebelum kebijakan diterapkan, diketahui bahwa perbedaan antara daerah inland dan daerah pesisir adalah sebesar 3.947 kemudian setelah adanya kebijakan maka perbedaan tersebut meningkat menjadi 3.961. Namun pada tahun 2017, perbedaan antara kedua daerah tersebut mengalami penurunan, yaitu menjadi 3.873. Artinya, pada tahun pertama setelah kebijakan, gap diantara kedua daerah semakin melebar, kemudian menyempit pada tahun kedua setelah kebijakan. Berdasarkan analisis tersebut adanya kebijakan desentralisasi fiskal berdampak pada peningkatan kualitas pembangunan manusia sebelum maupun sesudah kebijakan.

Indikator ketiga yaitu indikator ekonomi. Berdasarkan analisis DID dapat dilihat bahwa dengan kebijakan desentralisasi fiskal berpengaruh menurunkan gap pendapatan antara daerah inland dengan daerah pesisir pada tahun 2016 di Kabupaten/Kota Provinsi Jawa Barat. Sebelum kebijakan diterapkan, diketahui bahwa perbedaan antara daerah inland dan daerah pesisir adalah sebesar -0,376 kemudian setelah adanya kebijakan maka perbedaan tersebut berkurang menjadi -0,360. Begitu pula pada tahun 2017, perbedaan antara kedua daerah tersebut mengalami penurunan, yaitu menjadi $-0,356$. Artinya, pada tahun pertama setelah kebijakan, gap diantara kedua daerah semakin sempit, kemudian terus menyempit pada tahun kedua setelah kebijakan. Namun sama seperti Jawa Timur, baik sebelum dan sesuah kebijakan, daerah pesisir memiliki kinerja ekonomi yang lebih baik daripada daerah inland. Berdasarkan analisis tersebut adanya kebijakan desentralisasi fiskal tidak berdampak pada peningkatan ekonomi sebelum maupun sesudah kebijakan.

\section{Tabel 4}

Hasil Analisis Difference-In-Differences Indikator Capaian Hasil Pembangunan Jawa Barat, 2015 vs 2016

\begin{tabular}{|c|c|c|c|c|c|c|}
\hline \multirow{3}{*}{$\begin{array}{c}\text { Dampak Desentralisasi Fiskal } \\
\text { Terhadap Indikator Capaian Hasil } \\
\text { Pembangunan }\end{array}$} & \multicolumn{6}{|c|}{2016} \\
\hline & \multicolumn{3}{|c|}{$2015 v s 2016$ (Before) } & \multicolumn{3}{|c|}{$2015 v s 2016$ (After) } \\
\hline & Control & Treated & $\begin{array}{l}\operatorname{Diff}(\mathrm{T}- \\
\mathrm{C})\end{array}$ & Control & Treated & $\begin{array}{l}\operatorname{Diff}(\mathrm{T}- \\
\mathrm{C})\end{array}$ \\
\hline $\begin{array}{l}\text { Ketimpangan } \\
\text { (Indeks GINI) }\end{array}$ & 0.319 & 0.361 & $\begin{array}{l}0.042 * * \\
(0.019)\end{array}$ & 0.351 & 0.388 & $\begin{array}{c}0.037 * * * \\
(0.013)\end{array}$ \\
\hline $\begin{array}{l}\text { Pembangunan Manusia } \\
\text { (IPM) }\end{array}$ & 66.728 & 70.675 & $\begin{array}{c}3.947 * * * \\
(1.930)\end{array}$ & 67.606 & 71.567 & $\begin{array}{c}3.961 * * * \\
(1.365)\end{array}$ \\
\hline $\begin{array}{l}\text { Ekonomi } \\
\text { (PDRB) }\end{array}$ & 17.400 & 17.024 & $\begin{array}{l}-0.376 \\
(0.424)\end{array}$ & 17.473 & 17.113 & $\begin{array}{c}0.360 \\
(0.234)\end{array}$ \\
\hline
\end{tabular}

Keterangan: ***Signifikan pada level 1\%; **Signifikan pada level 5\%; *Signifikan pada level 10\% Sumber: Analisis Penulis (2020) 


\section{Tabel 5}

Hasil Analisis Difference-In-Differences Indikator Capaian Hasil Pembangunan Jawa Barat, 2015 vs 2017

\begin{tabular}{|c|c|c|c|c|c|c|}
\hline \multirow{3}{*}{$\begin{array}{c}\text { Dampak Desentralisasi Fiskal } \\
\text { Terhadap Indikator Capaian Hasil } \\
\text { Pembangunan }\end{array}$} & \multicolumn{6}{|c|}{2017} \\
\hline & \multicolumn{3}{|c|}{ (Before) } & \multicolumn{3}{|c|}{ (After) } \\
\hline & Control & Treated & $\begin{array}{l}\text { Diff }(\mathrm{T}- \\
\mathrm{C})\end{array}$ & Control & Treated & $\begin{array}{l}\text { Diff }(\mathrm{T}- \\
\mathrm{C})\end{array}$ \\
\hline $\begin{array}{l}\text { Ketimpangan } \\
\text { (Indeks GINI) }\end{array}$ & 0.319 & 0.361 & $\begin{array}{c}0.042 * * \\
(0.019)\end{array}$ & 0.352 & 0.382 & $\begin{array}{c}\mathbf{0 . 0 3 0} * * \\
(\mathbf{0 . 0 4 2})\end{array}$ \\
\hline $\begin{array}{c}\text { Pembangunan Manusia } \\
\text { (IPM) }\end{array}$ & 66.728 & 70.675 & $\begin{array}{c}3.947 * * * \\
(1.930)\end{array}$ & 67.952 & 71.825 & $\begin{array}{c}\text { 3.873*** } \\
(3.873)\end{array}$ \\
\hline $\begin{array}{l}\text { Ekonomi } \\
\text { (PDRB) }\end{array}$ & 17.400 & 17.024 & $\begin{array}{c}-0.376 \\
(0.424)\end{array}$ & 17.498 & 17.143 & $\begin{array}{c}-0.356 \\
(0.300)\end{array}$ \\
\hline
\end{tabular}

Keterangan: ***Signifikan pada level 1\%; **Signifikan pada level 5\%; *Signifikan pada level $10 \%$

Sumber: Analisis Penulis (2020)

Analisis DID juga disajikan dalam bentuk grafik yang bertujuan agar dapat melihat dampak dari kebijakan desentralisasi fiskal terhadap indikator capaian pembangunan dan juga gap antara daerah inland dengan daerah pesisir di Jawa Barat. Adapun dampak dan gap tersebut disajikan pada grafik berikut:

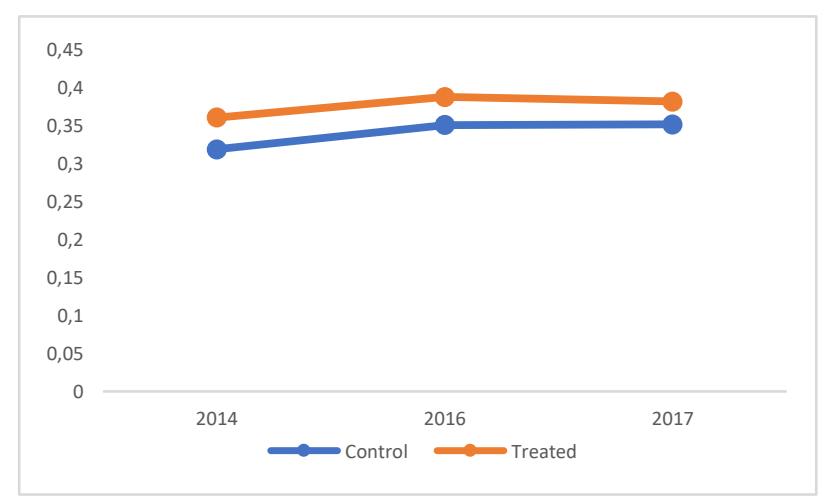

Gambar 5

Analisis Difference-In-Differences Indikator Ketimpangan Jawa Barat Sumber: Analisis Penulis (2020)

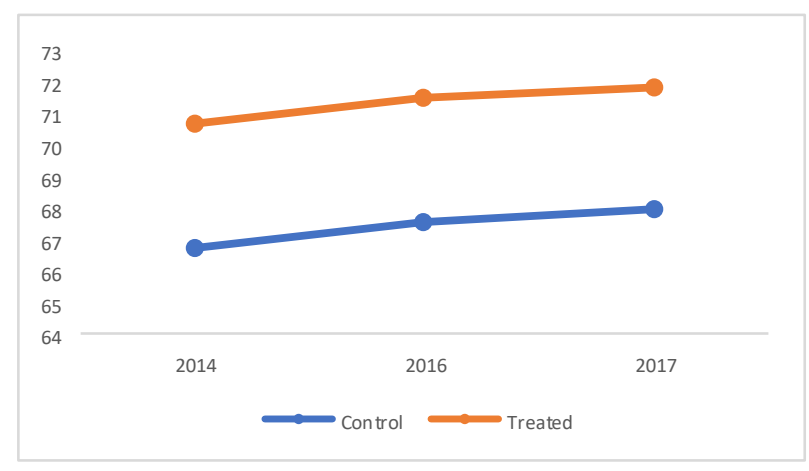

Gambar 6

Analisis Difference-In-Differences Indikator Ketimpangan Jawa Barat Sumber: Analisis Penulis (2020) 


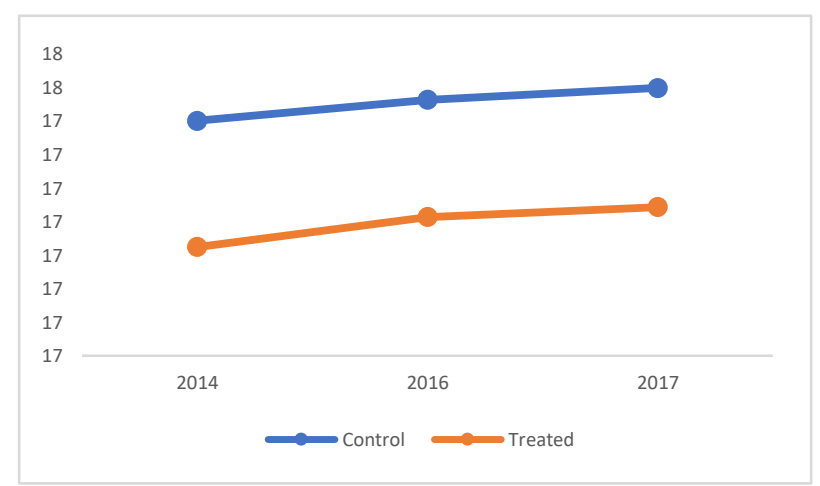

\section{Gambar 7}

Analisis Difference-In-Differences Indikator Ketimpangan Jawa Barat Sumber: Analisis Penulis (2020)

Pada bagian ini akan interpretasi pengaruh kebijakan desentralisasi fiskal terhadap indikator capaian pembangunan manusia pada tahun 2016 dan 2017 berdasarkan hasil regresi pada metode DID di Provinsi Jawa Timur dan Provinsi Jawa Barat. Daerah pertama adalah kabupaten/kota yang berada di Provinsi Jawa Timur. Berdasarkan hasil regresi pada metode DID, maka dapat diketahui bahwa kebijakan desentralisasi fiskal berpengaruh positif signifikan pada indikator ketimpangan sebesar 2,7 persen pada tahun 2016 dan 2,9 persen pada tahun 2017. Selain itu, kebijakan desentralisasi fiskal juga berpengaruh positif signifikan pada indikator pembangunan manusia yaitu sebesar 5,646 poin pada 2016 dan 5,572 poin pada 2017. Selanjutnya, kebijakan desentralisasi fiskal berpengaruh negatif signifikan terhadap indikator ekonomi yaitu sebesar -6,11 persen pada tahun 2016 dan -6,08 persen pada tahun 2017. Dari hasil tersebut, dapat ditarik tiga kesimpulan mengenai pengaruh kebijakan desentralisasi fiskal terhadap indikator capaian pembangunan di Provinsi Jawa Timur. Pertama, kebijakan desentralisasi fiskal tidak terbukti dapat menurunkan ketimpangan daerah. Namun, kebijakan desentralisasi fiskal terbukti dapat meningkatan kualitas pembangunan manusia daerah. Kebijakan desentralisasi fiskal juga tidak terbukti dapat meningkatkan ekonomi daerah. Kedua, bahwa respon terbesar daerah terhadap kebijakan desentralisasi fiskal adalah pada tahun pertama setelah kebijakan, khususnya pada indikator ketimpangan dan pembangunan manusia. Ketiga, kebijakan desentralisasi fiskal berpengaruh baik pada indikator pembangunan manusia dikarenakan pengaruh tersebut menunjukkan arah positif sesuai asumsi bahwa dengan adanya desentralisasi fiskal akan meningkatkan kualitas pembangunan manusia. 
Tabel 6

Analisis Regresi pada Metode DID Jawa Timur 2016-2017

\begin{tabular}{ccc}
\hline $\begin{array}{c}\text { Dampak Desentralisasi Fiskal Terhadap } \\
\text { Indikator Capaian Hasil Pembangunan }\end{array}$ & $\mathbf{2 0 1 5 v s 2 0 1 6}$ & $\mathbf{2 0 1 5 v s 2 0 1 7}$ \\
\hline Kemiskinan & $0.027^{* * *}$ & $0.029^{* * *}$ \\
(Indeks GINI) & $(0.007)$ & $(0.007)$ \\
\hline Pembangunan Manusia & $5.646^{* * *}$ & $5.572^{* * *}$ \\
(IPM) & $(1.043)$ & $(1.044)$ \\
\hline Pendapatan & $-0.611^{* * *}$ & $-0.608^{* * *}$ \\
(PDRB) & $(0.196)$ & $(0.196)$ \\
\hline
\end{tabular}

Keterangan: ***Signifikan pada level 1\%; **Signifikan pada level 5\%; *Signifikan pada level 10\% Sumber: Analisis Penulis (2020)

Daerah kedua adalah kabupaten/kota yang berada di Provinsi Jawa Barat. Berdasarkan hasil regresi pada metode DID, maka dapat diketahui bahwa kebijakan desentralisasi fiskal berpengaruh positif signifikan pada indikator ketimpangan sebesar 3,7 persen pada tahun 2016 dan 3,0 persen pada tahun 2017. Selain itu, kebijakan desentralisasi fiskal juga berpengaruh positif signifikan pada indikator pembangunan manusia yaitu sebesar 3,961 poin pada 2016 dan 3,873 poin pada 2017. Selanjutnya, kebijakan desentralisasi fiskal berpengaruh negatif tidak signifikan terhadap indikator ekonomi pada tahun 2016 dan 2017. Dari hasil tersebut, dapat ditarik tiga kesimpulan mengenai pengaruh kebijakan desentralisasi fiskal terhadap indikator capaian pembangunan di Provinsi Jawa Barat. Pertama, kebijakan desentralisasi fiskal tidak terbukti dapat menurunkan ketimpangan daerah, meskipun pada tahun 2017 peningkatan indikator kemiskinan menunjukkan penuruan persentase 3,0 persen. Sama seperti provinsi Jawa Timur, kebijakan desentralisasi fiskal terbukti dapat meningkatan kualitas pembangunan manusia daerah. Kebijakan desentralisasi fiskal juga tidak terbukti berpengaruh terhadap ekonomi daerah. Kedua, bahwa respon terbesar daerah terhadap kebijakan desentralisasi fiskal adalah pada tahun pertama setelah kebijakan, khususnya pada indikator pembangunan manusia. Pada indikator kemiskinan, respon terbaik terjadi pada tahun kedua setelah kebijakan. Ketiga, kebijakan desentralisasi fiskal berpengaruh baik pada indikator pembangunan manusia dikarenakan pengaruh tersebut menunjukkan arah positif sesuai asumsi bahwa dengan adanya desentralisasi fiskal akan meningkatkan kualitas pembangunan manusia

Tabel 7

Analisis Regresi pada Metode DID Jawa Barat 2016-2017

\begin{tabular}{ccc}
\hline $\begin{array}{c}\text { Dampak Desentralisasi Fiskal Terhadap Indikator } \\
\text { Capaian Hasil Pembangunan }\end{array}$ & $\mathbf{2 0 1 5 v s 2 0 1 6}$ & $\mathbf{2 0 1 5 v s 2 0 1 7}$ \\
\hline Kemiskinan & $0.037^{* * *}$ & $0.030^{* *}$ \\
(Indeks GINI) & $(0.013)$ & $(0.042)$ \\
\hline Pembangunan Manusia & $3.961^{* * *}$ & $3.873^{* * *}$ \\
(IPM) & $(1.365)$ & $(3.873)$ \\
Pendapatan & 0.360 & -0.356 \\
(PDRB) & $(0.234)$ & $(0.300)$ \\
\hline
\end{tabular}

Keterangan: ***Signifikan pada level 1\%; **Signifikan pada level 5\%; *Signifikan pada level 10\% Sumber: Analisis Penulis (2020) 
Berdasarkan analisis dengan menggunakan metode difference-in-differences, dapat diketahui bahwa kebijakan desentralisasi fiskal memiliki pengaruh terhadap penurunan ketimpangan pada indikator capaian pembangunan wilayah di daerah pesisir dan inland pada masing-masing provinsi. Selain itu, setelah adanya kebijakan desentralisasi fiskal, ketimpangan indikator capaian hasil pembangunan mengalami konvergensi di kedua wilayah. Artinya bahwa dengan setelah diterapkannya kebijakan desentralisasi fiskal maka gap antara daerah pesisir dengan daerah inland semakin sempit atau ketimpangan diantara kedua wilayah semakin berkurang. Hal tersebut sesuai dengan penelitian yang dilakukan oleh (Zulyanto, 2010), (Sasana, 2011), dan (Phelps et al., 2014) bahwa terdapat hubungan negatif antara kebijakan desentralisasi fiskal dengan ketimpangan wilayah dan terdapat pengaruh positif dari kebijakan desentralisasi pada konvergensi wilayah.

Temuan ini juga sesuai dengan penjelasan mengenai ketimpangan pembangunan dari Teori Neo-Klasik. Dijelaskan dalam teori Neo-Klasik bahwa pada permulaan proses pembangunan, ketimpangan pembangunan regional cenderung melebar (divergence). Proses ini akan terjadi sampai ketimpangan tersebut mencapai titik puncak. Selanjutnya, jika proses pembangunan terus berlanjut, maka akan menyebabkan semakin maju nya negara tersebut dan ketimpangan pembangunan regional akan semakin berkurang (convergence). Hal ini sesuai dengan hasil analisis yang dilakukan pada kedua wilayah, dimana sebelum kebijakan desentralisasi diterapkan terjadi ketimpangan diantara wilayah pesisir dan inland. Setelah adanya kebijakan desentralisasi, diketahui terjadi konvergensi ketimpangan pada indikator capaian pembangunan di wilayah pesisir dan inland. Peningkatan konvergensi juga terjadi pada tahun kedua setelah kebijakan diterapkan, yang ditunjukkan dengan nilai perbedaan yang jaraknya semakin menyempit. Selain itu, dari hasil analisis diketahui bahwa wilayah inland memiliki kinerja yang lebih baik dibandingkan wilayah pesisir pada indikator ketimpangan dan indikator pembangunan manusia. Sedangkan, pada indikator ekonomi, wilayah pesisir memiliki kinerja yang lebih baik dibandingkan wilayah inland. Temuan ini diduga disebabkan oleh adanya aktivitas perekonomian yang cukup tinggi didaerah pesisir, seperti Kabupaten Bekasi dan Kabupaten Karawang di Jawa Barat serta Kabupaten Gresik, Kota Surabaya, dan Kabupaten Sidoarjo di Jawa Timur. Hal ini sesuai dengan (Bunnell et al., 2013) yang menjelaskan bahwa wilayah yang berada di pesisir memiliki aktivitas perdagangan, dalam hal ini adalah kegiatan ekspor, yang lebih baik dibandingkan wilayah inland sehingga berpengaruh terhadap pertumbuhan ekonominya.

Temuan selanjutnya yaitu diketahui bahwa di kedua wilayah penelitian, gap antara daerah pesisir dan inland pada indikator ketimpangan sudah cukup sempit namun pada indikator pembangunan manusia dan pendapatan masih cukup lebar. Hal ini menunjukkan bahwa distribusi pendapatan di kedua wilayah yakni pesisir dan inland sudah cukup merata di wilayah pesisir dan inland sehingga tidak menunjukkan gap perbedaan yang besar diantara keduanya, meskipun kabupaten/kota yang termasuk 
didalam kategori wilayah inland masih diketahui memiliki ketimpangan yang lebih tinggi dibandingkan dengan daerah yang masuk dalam kategori pesisir. Di Jawa Barat, hal ini diduga salah satunya akibat dari adanya perbedaan upah minimum yang cukup signifikan di Kabupaten/Kota di Jawa Barat. Perbedaan upah minimum ini tentunya akan mempengaruhi pola pengeluaran perkapita di tiap-tiap daerah. Hal inilah yang diduga menjadi salah satu penyebab adanya ketidak merataan pada distribusi pendapatan di Jawa Barat. Sedangkan di Jawa Timur, adanya ketimpangan ini diduga salah satunya dalah faktor ketersediaan aksesibilitas yang lebih baik pada daerah yang berada di utara dibandingkan dengan daerah yang berada di selatan Jawa Timur. Pada indikator pembangunan manusia, diketahui bahwa masih terdapat gap yang cukup lebar di kedua wilayah. Begitu pula dengan indikator perekonomian yang diketahui masih menunjukkan gap yang cukup besar meskipun mengalami konvergensi.

Temuan selanjutnya yaitu diketahui bahwa di Jawa Timur respon terbesar daerah terhadap kebijakan desentralisasi fiskal terjadi pada tahun pertama pada seluruh indikator capaian hasil pembangunan. Sedangkan di Jawa Barat, respon terbesar daerah terhadap kebijakan desentralisasi fiskal terjadi pada tahun pertama pada indikator pembangunan manusia sedangkan tahun kedua pada indikator kemiskinan. Oleh karena itu, berdasarkan hasil analisis Jawa Timur memiliki respon yang lebih cepat pada kebijakan desentralisasi fiskal. Hal ini menunjukkan tidak terpenuhinya asumsi semakin dekat suatu wilayah dengan pusat pengambilan kebijakan maka diasumsikan semakin cepat dampak yang akan dirasakan oleh wilayah tersebut. Sebaliknya, semakin jauh suatu wilayah dengan pusat pengambilan kebijakan maka diasumsikan dampak yang akan dirasakan oleh wilayah tersebut akan lebih lambat, khususnya pada indikator kemiskinan.

\section{Kesimpulan}

Berdasarkan pembahasan pada bab sebelumnya yang mengacu pada proses dan hasil analisis data dalam penelitian maka diapat diambil kesimpulan yaitu kebijakan desentralisasi fiskal memiliki pengaruh terhadap penurunan ketimpangan pada indikator capaian pembangunan wilayah di daerah pesisir dan inland pada masing-masing provinsi. Hal tersebut ditunjukkan oleh hasil analisis DID bahwa pada tahun pertama dan kedua setelah kebijakan diterapkan, gap kinerja indikator capaian pembangunan wilayah antara daerah pesisir dan inland mengalami penurunan. Setelah adanya kebijakan desentralisasi fiskal, ketimpangan indikator capaian hasil pembangunan mengalami konvergensi di kedua wilayah. Artinya bahwa dengan setelah diterapkannya kebijakan desentralisasi fiskal maka gap antara daerah pesisir dengan daerah inland semakin sempit atau ketimpangan diantara kedua wilayah semakin berkurang. Pada kedua provinsi menunjukkan hasil analisis yaitu daerah pesisir mampu mengejar ketertinggalan dari daerah inland pada indikator kemiskinan dan pembangunan manusia, sedangkan pada indikator pendapatan, daerah inland mampu mengejar ketertinggalan dari daerah pesisir. Hasil dari analisis tersebut sesuai dengan penelitian yang dilakukan oleh Canaleta, bahwa terdapat hubungan negatif antara kebijakan 
Sekar Dewinda Santi dan Doddy Aditya Iskandar

desentralisasi fiskal dengan ketimpangan wilayah dan terdapat pengaruh positif dari kebijakan desentralisasi pada konvergensi wilayah. 


\section{BIBLIOGRAFI}

Bunnell, T., Miller, M. A., Phelps, N. A., \& Taylor, J. (2013). Urban Development In A Decentralized Indonesia: Two Success Stories? Pacific Affairs, 86(4), 857-876.

Dafflon, B. (2015). The Assignment Of Functions To Decentralized Government: From Theory To Practice. In Handbook Of Multilevel Finance. Edward Elgar Publishing.

Fadzil, F. H., \& Nyoto, H. (2011). Fiscal Decentralization After Implementation Of Local Government Autonomy In Indonesia. World Review Of Business Research, 1(2), 51-70.

Faguet, J.-P. (2014). Decentralization And Governance. World Development, 53, 2-13.

Hadi, S., \& Saragih, T. M. (2013). Ontologi Desentralisasi Fiskal Dalam Negara Kesatuan. Perspektif, 18(3), 169-179.

Hidayat, R. (2017). Political Devolution: Lessons From A Decentralized Mode Of Government In Indonesia. SAGE Open, 7(1), 2158244016686812.

Hill, H. (2014). Regional Dynamics In A Decentralized Indonesia (Vol. 501). Institute Of Southeast Asian Studies.

Kalirajan, K., \& Otsuka, K. (2012). Fiscal Decentralization And Development Outcomes In India: An Exploratory Analysis. World Development, 40(8), 15111521.

Kharisma, B. (2013). Desentralisasi Fiskal Dan Pertumbuhan Ekonomi: Sebelum Dan Sesudah Era Desentralisasi Fiskal Di Indonesia. Jurnal Ekonomi \& Studi Pembangunan, 14(2), 101-119.

Kusuma, H. (2016). Desentralisasi Fiskal Dan Pertumbuhan Ekonomi Di Indonesia. Desentralisasi Fiskal Dan Pertumbuhan Ekonomi Di Indonesia, 9(1), 1-11.

Nasution, A. (2017). The Government Decentralization Program In Indonesia. In Central And Local Government Relations In Asia. Edward Elgar Publishing.

Naylor, R. L., Higgins, M. M., Edwards, R. B., \& Falcon, W. P. (2019). Decentralization And The Environment: Assessing Smallholder Oil Palm Development In Indonesia. Ambio, 48(10), 1195-1208.

Phelps, N. A., Bunnell, T., Miller, M. A., \& Taylor, J. (2014). Urban Inter-Referencing Within And Beyond A Decentralized Indonesia. Cities, 39, 37-49.

Sasana, H. (2011). Analisis Determinan Belanja Daerah Di Kabupaten/Kota Provinsi Jawa Barat Dalam Era Otonomi Dan Desentralisasi Fiskal. Jurnal Bisnis Dan Ekonomi, 18(1), 24285. 
Sekar Dewinda Santi dan Doddy Aditya Iskandar

White, S. (2011). Government Decentralization In The 21st Century. A Literature Review: A Report Of The CSIS Program And Crisis, Conflict And Cooperation, CSIS, Washington, DC, December.

Yustisia, T. V. (2015). Undang-Undang No 23 Tahun 2014 Tentang Pemerintahan Daerah Dan Perubahannya. Visimedia.

Zulyanto, A. (2010). Pengaruh Desentralisasi Fiskal Terhadap Pertumbuhan Ekonomi Di Provinsi Bengkulu. Universitas Diponegoro. 